AN ADDRESS

DELIVERED AT THE OPENING OF

\section{THE SECTION OF OTOLOGY.}

At the Annual Meeting of the British Medical Association in Brighton, August, 1886.

BY G. F. HODGSON, M.R.C.S.Eng.,

President of the Section.

PROGRESS OF AURAL SURGERY DURING THE PRESENT CENTURY.

Gentlemen, - On behalf of my coadjutors, and on my own part, I have the pleasure to offer all of you who are visitors a hearty welcome, and to express the hope that your short stay in our town will be pleasurable enough to induce you soon to revisit it.

At these annual gatherings, it has become customary for the chairman of each section to open it by some introductory remarks. On the present occasion, I will endeavour to occupy the time by very briefly reviewing the progress which our specialty has made (at least medically and surgically) during the present century.

This poriod of above eighty years will indeed include the history of about all that can be recorded on the subject, to any purpose; as although the anatomy of the organ of hearing had been fairly well made out for a century or more previously, a knowledge of its diseases and their suitable treatment could not be said to exist; what was thought and done being not only devoid of common sense, but for the most part empirical, not to say absurd, and sometimes even disgusting.

In 1806, Mr. John Cunningham Saunders (Demonstrator of Practical Anatomy at St. Thomas's Hospital) brought out the first book, of English origin, that put aural surgery on a clearer and sounder footing. He classified the diseases as they respectively affect the outer, middle, and internal portions of the organ ; and, although his means of diagnosis were very defective, yet, by making numerous careful dissections of the ears of deceased persons who had been deaf, he obtained valuable information wherewith to guide his notions of pathology and treatment. He pretty successfully treated otorrhœe and polypus, practised paracentesis of the membrane for tympanal suppuration, and showed that neglected suppuration of the ear might lead to brain-disease. Some six years previously, Mr. Cooper (afterwards Sir Astley) had, at the suggestion of Sir Everard Home, punctured the membrane in a few cases in which the Eustachian tube was supposed to be impervious, with the ohject of letting air into the drum-cavity. No speculum was known to these surgeons, but their operations were performed with the aid of sunlight directed into the meatus.

Saunders also did not adopt the Eustachian catheter, although two other Englishmen (Cleland and Wathan) independently had invented and used it, for both air and fluids, about half-a-century previously. Indeed, Saunders seems to have known but little of non-suppurative tympanal disease. His notions of labyrinthine affections were also very vague, the presence of tinnitus being considered by him as an important symptom of it. His treatment of tinnitus, too (eight grains of calomel at night, followed by an ounce and a half of sulphate of soda in the morning, daily for a fortnight) would not harmonise with the present views of either surgeons or patients. Saunders died young, only four years after the publication of his book; but this sabsequently was edited and republished several times.

Thirty vears afterwards, Kramer of Berlin, and two years later, Pilcher of London, each brought out a book on diseases of the ear, Kramer's soon being put into English dress by Dr. J. R. Bennett. Both of these authors dwelt much on the importance of Eustachian treatment :- Kramer by means of the catheter and a metallic air-pump for forcing in air and vapours to the tympanum, and Pilcher by using bougies and stilettes, and sending in fluid injections by the catheter and a syringe.

Kramer's treatise held sway for many years ; although his air-pump soon fell into disuse in England, especially after the occurrence in London of two sudden deaths during its employment by a practitioner in Gower Street. Emphysema of the throat, implicating the glottis, as supposed to be the effect, the mucous membrane having been torn first by the point of the catheter. A case of emphysema of the neck, whilst using the catheter and air-press, occurred to Pilcher, but it did not prove fatal. One would suppose that in these cases the catheters had not button-ends. Eren now I meet with such instruments in some of the shops, but surely they find bat few purchasers. A shorter instrument also I much prefer ; it remains in position much more readily. Some years ago, I had all mine abbreviated by a silversmith, who cut out nearly one inch and a half of the tube, and then reunited the ends. Such shorter instruments are now made by Mayer and Meltzer, at the suggestion, I believe, of Dr. Woakes. (Here are some of them.)

In 1848, in the Lancet for July 1st, Mr. Yearsley made public his fortunate discovery of the so-called "cotton-wool drum," the value of which is still considered as great as then. If Saunders had lived longer, one can imagine that he might have hit upon some. thing of the sort, as he seems to have been much struck with the fact that one or two of his patients heard remarkably better whilst a drop or two of fluid (even if it were pus) was in contact with the maimed membrane. Most of us, I suppose, have met with similar instances.

During the decade from 1850 to 1860 , Wilde of Dublin, and Toynbee of London, came to the front, the former advancing aural surgery in a thoroughly practical and common-sense manner. The polypus snare, a free incision down to the mastoid process, and the tubular speculum are identified with his name; the speculum, however, being modified from Gruber's, and perhaps not thereby improved.

Toynbee (a fellow-student with myself, but a few years older), by his painstaking and indefatigable dissections, put the pathological anatomy of the ear on a footing never previously approached, and which has largely helped forward a more correct understanding of the subject. Like Saunders, Toynbee died young.

It would appear that it was in consequence of Toynbee having drawn attention to the normal condition of the Eustachian tube being closure (except under the influence of some muscular action, such as swallowing), that Politzer was led to work out his simple and now well-known method of inflating the drum-cavity. This happy invention, like Yearsley's artificial drum, added immensely to our means of curing or mending several forms of deafness ; and it came most opportunely, as after the abolition of Kramer's air-press, no satisfactory substitute had been hit upon. Toynbee had even resorted to blowing his own breath along the catheter.

The name of Politzer brings us to within a quarter of a century of the present day. During this period, increased activity has sprung up, most civilized countries having furnished men who have made advances in otological knowledge. Thus, Lucae and Politzer have taught us the use of the tuning-fork; trephining the mastoid (which Petit originated in 1774) has been revived by Troltsch, James Hinton, and some Americans, and been fully established as an orthcdox proceeding. In passing, I may just show this neatly made drill (miniatured by Mayer and Meltzer from a coarser implement in use by American mechanics), as, to my mind, the most ready instrument for letting-out pus from the mastoid cells; and the movable check, fitted to it at my suggestion, makes its use quite safe. Troltsch again has given us a simple, but effectual, mode of illuminating the meatus and the drum-membrane; and the laryngscope, reversed, serves us well for examining the pharynx and posterior nares; whilst, during the same space of time, numerous books aud monographs have appeared, wherein not only the minuter anatomy (healthy and norbid) and physiology of the ear, but also the general principles and varions details of aural surgery, have been described with as much accuracy as characterizes other branches of surgery.

Amongst these instructive works, one cannot refrain from mentioning with appreciation the Archives of Otology (German and American); Politzer's Monograph on the Membrana Tympani ; Peter Allen's Lectures at St. Mary's Hospital ; Dalby's Lectures at St. George's Hospital ; and especially Hinton's Questions of Aural Surgery, and his beautiful atlas of the membrana tympani, with its 150 figures, hand-coloured by Mrs. Hinton. "Adenoid growths in the naso-pharyngeal space," have been made much of by Meyer, of Denmark; and Woakes has endeavoured to elucidate the mysteries of giddiness and tinnitus. I suppose that the climate of Brighton is not favourable to the development of these adenomata. Anyhow, I have never met with such large growths as Meyer describes ; and, as remedies, bracing constitutional tonics, and strong local astringents (especially a saturated solution of tannin in spirits of chloroform), with, rarely, the use of this little home-made steel finger-nail, have sufficed with me.

Now that I am speaking of Brighton, I may incidentally say that, although I have practiced here for forty years, I have met with nothing to support the theoryiadvanced by some aural surgeons, that exostoses of the meatus owe thoir origin to sea-bathing, although. I have known prolonged." side-stroke" swimming in the sea cause severe ordinary otitis on the submerged side.

The still more recent literary productions are too fresh in the minds 
of us all to need allusion to them, unless to show that on all sides, the ovidence of to.day amply proves that. Otology is fairly abreast of the tarious other branches of the healing art.

The very existeme, indeed, of this " "Section": itselt, helps to strengthen this position; and I will venture to trust that the fact of this Section being presided over, on the : present occasion, by a "general practitioner," may not only not lessen the value of its work, but that, it may, even tend, in some measure, to convince general practitioners, as a body, that a decent : knowledge of aural surgery is quite within their reach, and should receive a share of their attention.

In conclusion, as a still further proof of modern gains in connection with our speciality, I may just allude to those cases in which surgical skill is hopeless-the simply deaf may yet be helped by an improved instrumental conveyer of sound, and "lip-reading" may. save the deaf-dumb from social exclusion.

Gentlemen, I thank you for your patient endurance of what, I fear, has' been rather an ordeal.

\section{FIFTY-FOURTH ANNUAL MEETING.}

\section{OF THE}

\section{BRITISH MEDICAL ASSOCIATION,}

\section{Held in BRIGHTON, August, 10th, 11th, 12th, and 13th, 1886.}

Frrst Graneral Megting: Tuesday, August 10th, 1886.

Tea : first general meeting was held in the Dome of the Pavilion, Brighton; at 3 P.M.; on Tuesday, August 10th.

The chair was taken by Dr. W. T. EDwARDs, President for 1885-86. The minutes of the previous meeting were confirmed.

Address of Retiring President.-Dr. EDwARDs, in resigning the chair, said he desired most heartily to thank the members of the Asseciation for the great distinction that had been conferred upon him. The year in anticipation of his appointment had been one of great anxiety. He felt himself unfitted for so responsible 2 position, but, by the kindness of the South Wales Braneh, and the courtesy of all the officials of the Association, he hoped he had been able to discharge his duties in such a way as to promote the interests of the Association. He had great pleasure in knowing that the chair was this year to be filled by their worthy representative, Dr. Withers Moore; he was so well known as an active member of the Council, a distinguished member of the profession, that it was unnecessary to say anything in his praise. They were all well assured that in his hands the duties of his office would be worthily discharged. Again thanking the members for their kindness, he asked Dr. Withers Moore to take the chair.

Dr. Withers Moore, in taking the chair, said be desired, on behalf of the municipal authorities of the town, and of his. professional brethren, to bid the Association a hearty welcome to Brighton. They were honoured by an unusually large number of visitors. It might be invidious to single out any of them, but, thore being a very large contingent from the United States, he might be permitted to mention one name-that of Dr. Davis, the President-elect of the International Medical Congress, - on $\theta$ of the most popular men in his country. They heartily welcomed him to England, as indeed they did all their foreign visitors. The Local Executive Committee had done all in their power to conduce to the comfort and convenience of the members, who, it was hoped, would have a prosperous, pleasant, and profitable meeting, which might take rank with the most successful of its predecessors.

Vote of Thanks to Dr. Edwards.-Dr. E. WATERS (Chester) congratulated Dr. Withers Moore on his assumption of the duties of President, a position to which he had been promoted not only by the good-will of the profession in Brighton-those who had known him so long and so well-but also by the universal voice of the Association. In proposing a vote of thanks to their outgoing President, Dr. Edwards, ? who was elected to the chair at their meeting in Cardiff, he said his recollection of Cardiff went back a great many years, to time when, passing through it as a small country town where the mail changed horses, it had, he believed, something like 1,200 inhabitants. The then small hamlet was now a town of 120,000 inhabitants, full of life, full of prosperity, full of intellect, and the seat of one of the rieing schools of learning that he trusted they would one day see flourishing in Wales. Dr. Edwards occupied a prominent position in connection with the University of Wales, of which there was a college founded 'in 'Cardiff, and in' that respect showed his warm interest in all that promoted the advance of education in that country. He moved :

"That the cordial thanks of the Association be given to Dr. W. T. Edwards for the courteous and able manner in which he has filled the office of President duiring the past, twelve months, and that he be elected a Vice-President for life."

He believed that, in carrying that resolution, they would have placed on the list of their permanent officers one who would always be attentive to his duties, and would promote in every way the future good and welfare of the Association.

Dr. CHADWICK (Tunbridge Wells) in seconding the resolution, which he dia with ( unmingled satisfaction, said there was one point that he wished particularly to emphasise. In order to the prosperity and progress of the Association, it was a matter of vital importance to those gentlemen who received its honours and discharged them so effectively that they should keep those honours in mind, and not let the Assaciation; so far as they were concerned; be: cast aside as a useless thing, except as contributing to their honour for the time being $\mathrm{He}$ Was not afraid to make use of this sort of representation to the outgoing President, because he could appeal to his own conduct for twenty years since he had been President; and therefore, when he said that the Association had a right to expect that they world not forget the source whence their honours had been derived, he was. sure that he should be excused.

The Presidens said, in putting the resolution, that he felt how difficult it would be to follow so able and courteous a President as their friend, Dr. Edwards.

The resolution was carried by acclamation

Dr. EDWARDs said he was very grateful for the very handsome manner in which Dr. Waters and Dr. Chadwick had referred to his services, and for his appointment as Vice-President for life. His election to the office of President had been the greatest honour he had received during his professional career. To have received such a mark of confidence from his professional brethren, and then to be elected a Vice-President of the Association, was a distination of which any medical men might well be proud, and he hoped that whatever af life and energy might be left to him would be devoted to the promotion of the best interests of the Association. He had been happily thrown into contact with the must earnest men in the profession anxious to promote its dignity and advance the learning and education of the youth now aspiring to enter it; and he hoped that by the means of the Association they would be all the more fitted to take their stand among the honourable professions of the country.

Rsport of Council - The Report of Council, which was published at page 273 of the JourNal of August 7th, was read, the following supplement being added.

Since this report was written, the awards of the adjudicators have been submitted to your Council. In the case of the Stewart Prize, the adjudicators, Dr. George Buchanan, Dr. Grainger Stewart, and Dr. Walter Dickson, have reported in favour of Dr. Robert Cory, who has made valuable and important work on the subject of vaccination. The report of the adjudicators is published in the JOURNAL of July 31 st, page 225 . There were five long essays sent in for competition for the Middlemore Prize; and, after careful consideration, the adjudicators, Dr. Argyll Robertson and Mr. Nettle. ship reported that, of the five excellent essays sent in, the two bestbearing the mottoes of "Ars longa, vita brevis," and "Nichts neues" - were so equally balanced in merit, that they advised the prize shouid be equally divided between their authors. On opening the envelopes with these mottoes, your Council found that the names of the authors were Mr. John Berry and Mr. Adams Frost. The cordial thanks of the Association are due to Dr. Walter Dickson, Dr. George Buchanan, and Dr. Grainger Stewart, for their careful con sideration, for the great amount of valuable and! impartant work already done by recent investigators on epidemiological subjects, both at home and abroad, and to Dr. Argyll Robertson and Mr. Nettleship for their arduous labours in reading through five large essays on the subject of recent advances in ophthalmological science. The successful competitors have been asked to attend the general meeting of Thursday, immediately after the Address in Surgery : has been delivered, when the prizes will be presented to them.

Sir. W. Fostre (who had been congratulated by the President on his knighthood) said the kindly words that had been spoken from the chair, and endorsed by his fellow-associates, were exceedingly pleasant and grateful to him. Any distinction like that which he had roeeived was. a distinction only when it came from professional work, and on account of service rendered to one's fellow-creatures. He beliered it had been in the main due to the faot that he had been honoured by them in being 